Karstenia 45: 91-102, 2005

\title{
Taxonomy of the Oligoporus hibernicus complex (Basidiomycota), with the new species O. parvus
}

\author{
PERTTI RENVALL
}

\begin{abstract}
RENVALL, P. 2005: Taxonomy of the Oligoporus hibernicus complex (Basidiomycota), with the new species O. parvus. - Karstenia 45: 91-102. ISSN 0453-3402.

The taxonomy of the Oligoporus hibernicus (Berk. \& Broome) Gilb. \& Ryvarden complex (Basidiomycota) is revised. The study is based on extensive herbarium material chiefly from northwestern Europe and the type material of the taxa involved. The examination of the type of Polyporus hibernicus Berk. \& Broome revealed that the name has been misapplied. The name belongs to a taxon, which often has pale yellow basidiocarps and was often erroneously called Physisporus flavicans P. Karst. or Poria johnstonii Murrill, and recently described as Oligoporus septentrionalis Vampola. The name $O$. parvus Renvall is proposed for the species that has erroneously been called as $O$. hibernicus in northwestern Europe. Four morphologically very similar species are recognized in the O. hibernicus complex in Europe: O. hibernicus sensu typi, O. perdelicatus (Murrill) Gilb. \& Ryvarden, O. simanii (Pilát) Bernicchia, and the new species $O$. parvus, which is reported from Finland, Norway and Sweden. O. perdelicatus has been collected from seven localities in eastern Finland and is here reported as new to Europe. The species are described and discussed in detail.
\end{abstract}

Key words: Aphyllophorales, Oligoporus, polyporaceous fungi, Postia hibernica, taxonomy

Pertti Renvall, Kuopio Natural History Museum, Myhkyrinkatu 22, FI-70100 Kuopio, Finland; e-mail pertti.renvall@kuopio.fi

\section{Introduction}

Tyromycetoid polypore species in the genera Oligoporus Bref., Postia Fr., and Tyromyces P. Karst. (Basidiomycota) present still many, more or less hidden taxonomical challenges. This is the case even in northwestern Europe (see e.g. Berglund \& Ryvarden 2000, Ryvarden et al. 2003, Niemelä et al. 2004), where the polypore flora may be the best known in the world (see Ryvarden 1978, Ryvarden \& Gilbertson 1994, Hansen \& Knudsen 1997, Niemelä 2005). Oligoporus hibernicus (Berk. \& Broome) Ryvarden \& Gilb. (Postia hibernica (Berk. \& Broome) Jülich) and its look-alikes, i.e. the group of brown-rot fungi with mostly inconspicuous, resupinate to effused-reflexed, white to pale yellow basidiocarps, monomitic hyphal structure, cylindrical to allantoid spores and variably present hymenial cystidia, give a good example of such taxonomical puzzle. Modern manuals (e.g. Ryvarden \& Gilbertson 1994) list three European taxa in the complex: O. hibernicus, O. septentrionalis and $O$. simanii. The first two have been reported, e.g. from Finland, Norway and Sweden (e.g. Hansen \& Knudsen 1997, Ryvarden et al. 2003, Niemelä 2004), while $O$. simanii is considered to have a more southern distribution (e.g. Bernicchia 2005).

I here revise the taxonomy of the so called Oligoporus hibernicus group in Europe. The idea to take a closer look on these taxa came into my mind already in 1987-1993 when I collected material in northeastern Finland (Renvall et al. 1991, Renvall 1995). My specimens did not always match with the descriptions in contempo- 
rary manuals (Ryvarden 1978, Ryvarden \& Gilbertson 1994) and other papers.

Still in the 1990's the collections of Oligoporus hibernicus s. lato (including O. septentrionalis Vampola) were relatively few, and the taxa of this group were considered to be rare in northwestern Europe (Ryvarden \& Gilbertson 1994, Hansen \& Knudsen 1997). The scantiness of collections enhanced difficulties in understanding the morphological variation of the species and their growth site ecology. Among others, Ryvarden and Gilbertson (1994) noted that this complex of species is difficult and more collections are needed to fully understand their range of variation.

During the last ten years plenty of new materials have been collected in various studies (e.g. Sippola \& Renvall 1999, Halonen et al. 2002) and, especially, in the old-growth forest inventories in northern and eastern Finland (e.g. Niemelä \& Dai 1999, Niemelä et al. 2005). Also plenty of unpublished herbarium material are available for this group. All this valuable new data have facilitated the understanding of the taxonomy of this group and give now better tools to evaluate the distributions and vulneralibility of the taxa.

\section{Materials and methods}

Altogether 180 specimens filed under Oligoporus hibernicus (Postia hibernica), O. septentrionalis (Postia septentrionalis), O. simanii (Postia simanii), Physisporus flavicans P. Karst., Tyromyces subsericeomollis (Romell) J. Erikss. or T. johnstonii (Murrill) Ryvarden were studied in the herbaria GB (incl. the collections established by J. Eriksson, Department of Systematic Botany; abbreviated as GB-J.E.), $\mathrm{H}$ (incl. the educational collections of T. Niemelä; H-T.N.), KUO, O (incl. the personal herbarium of L. Ryvarden; O-L.R.), S, UPS and the personal herbaria of H. Kotiranta (H.K.; Helsinki), R. Penttilä (R.P.; Helsinki). In addition, some specimens tentatively labelled as Oligoporus hibernicus from old-growth forest inventories in eastern and northern Finland were checked.

The holotypes of Oligoporus hibernicus, O. perdelicatus, $O$. septentrionalis and $O$. simanii were examined, as well as paratypes of Postia minuta Rajchenb. In addition, some specimens of Oligoporus inocybe (A. David \& Malençon) Ryvarden \& Gilb. and Postia venata (Rajchenb. $\&$ J.E. Wright) Rajchenb. were checked. The specimens of $O$. hibernicus, O. perdelicatus, O. septentrionalis and $O$. simanii are listed under their descriptions, and the studied specimens of related species are listed below.

Microscopical characters were studied at magnifications up to $\times 1250$ by using Leica DMLS microscope with phase contrast illumination. Anatomical details were drawn with the aid of a drawing tube. Cotton Blue (CB) was the mounting medium used when drawing the figures and when making measurements. IKI refers to Melzer's reagent and $\mathrm{KOH}$ to $5 \%$ potassium hydroxide, $\mathrm{CB}+$ means cyanophilous, $\mathrm{CB}-$ acyanophilous, and IKI- with neither amyloid nor dextrinoid reaction. Brands and formulas of these reagents have been explained by Niemelä et al. (2004).

Spores were measured from sections cut from the tubes. In presenting the variation of the basidiospore size, $5 \%$ of the measurements have been excluded from each end of the range, and are given in parentheses. Basidia, cystidia, cystidioles and hyphae were measured to the nearest 0.5 $\mu \mathrm{m}$. In the text the following abbreviations are used: L $=$ the mean spore length (arithmetical mean of all the spores), $\mathrm{W}=$ the mean spore width (arithmetical mean of all the spores), $\mathrm{Q}=$ quotient of the mean spore length and the mean spore width (L/W ratio; variation of the specimen means), $\mathrm{n}=$ the number of measured spores (basidia, cystidia, hyphae) from given number of specimens.

Authors of the species are according to Kirk and Ansell (1992), and the public herbaria are abbreviated according to Holmgren and Holmgren (1998 onwards). The nomenclature as well as the delimitation of polypore genera are still unstable. This concerns also the genera Oligoporus and Postia (see Donk 1960, Gilbertson \& Ryvarden 1985, 1987, Ryvarden 1991, Renvall 1992, Pieri \& Rivoire 1998). Mostly for practical reasons this paper follows the interpretation proposed by Ryvarden and Gilbertson (1994).

Additional specimens examined: Oligoporus inocybe (A. David \& Malençon) Ryvarden \& Gilb.: Portugal. Estremadura: Lisboa 1985 Melo, Correia \& Cardoso 2625 (H), Monsanto 1985 Melo \& Cardoso $6032(\mathrm{H})$. Italy. Pineta di Bibbona (Livorno) 1985 Bernicchia 4336 (HUBO), Riserva di Burano (Grosseto) 1991 Bernicchia 5434 (HUBO).

Poria johnstonii Murrill: U.S.A. California: 1918 Johnston 252 (isotype; K)

Postia minuta Rajchenb.: Argentina. Chubut 1995 Rajchenberg 10986 (paratype; CIEFAP), Neuquén 2000 Rajchenberg 11977 (paratype; CIEFAP), Rio Negro 2000 Rajchenberg 11995 (paratype; CIEFAP).

Postia venata (Rajchenb. \& J.E. Wright) Rajchenb.: Argentina. Rio Negro 1999 Rajchenberg 11893 (KUO). Neuquén 2000 Rajchenberg 12009 (KUO).

\section{Taxonomy}

The present study revealed both unsolved taxonomical problems and some unwelcome nomenclatural misapplications in the Oligoporus hibernicus complex. Four morphologically very similar species, including one undescribed, should be recognized in Europe: O. hibernicus sensu typi, O. perdelicatus (Murrill) Gilb. \& Ryvarden, $O$. simanii (Pilát) Bernicchia and a new species $O$. parvus. The discussions on the nomenclature and taxonomy of these taxa and their revised descriptions are given below. Spore measurements of the species (including types) are presented in Table 1. Representative in situ photographs of $O$. hi- 
bernicus s. typi, O. parvus and $O$. perdelicatus are found in Niemelä (2005). O. simanii has been illustrated, e.g. by Bernicchia (1990).

Oligoporus hibernicus (Berk. \& Broome) Gilb. \& Ryvarden sensu typi

Polyporus hibernicus Berk. \& Broome was validly described on the basis of evidently a single specimen collected on Pinus in Ireland (holotype in K, examined; Berkeley \& Broome 1871). This name was practically forgotten until Ryvarden (1974) refound it and transferred it into the genus Tyromyces. He proposed that Tyromyces hibernicus (Berk. \& Broome) Ryvarden is the correct, older name for the poorly known taxon called at that time as T. subsericeomollis (Romell) J. Erikss. by some Nordic mycologists (Eriksson 1958; misapplied name see Donk 1972, 1974). That little, white-coloured species has hyphoid hymenial cystidia and cylindrical spores 1.6-2.0 $\mu \mathrm{m}$ thick. Below I am calling it the "white/cystidiate taxon". This interpretation was followed in many subsequent papers. Now the species is included either in the genus Oligoporus (Gilbertson \& Ryvarden 1985) or Postia (Jülich 1982).

When Ryvarden (1974) reintroduced the name, two closely related species were recognized in this species complex in northwestern Europe: $T y$ romyces hibernicus (as T. subsericeomollis), and T. johnstonii (Murrill) Ryvarden (Physisporus flavicans P. Karst. sensu Romell, non sensu typi, see Lowe 1956) - an even less collected species characterized by yellow pore surface (Ryvarden 1970). In his Nordic polypore flora Ryvarden (1978) concluded that the two taxa are almost identical, and the latter is separated mainly by the yellow colour.

Vampola (1991) realized that the type of Tyromyces johnstonii (Poria johnstonii Murrill, in $\mathrm{K}$; studied) belongs to Diplomitoporus lindbladii (Berk.) Gilb. \& Ryvarden, and therefore he renamed the often yellow-pored, acystidiate and shorter-spored taxon (hereafter "yellow taxon") as Oligoporus septentrionalis Vampola. I agree with Vampola (1991) that the type of Poria johnstonii belongs to Diplomitoporus lindbladii. However, instead of Oligoporus septentrionalis, an older, valid and legitimate name is available for "the yellow taxon".

The examination of the type materials revealed that the name Oligoporus hibernicus (or
Postia hibernica) has been widely misapplied. Unlike proposed by Ryvarden $(1974,1978)$ and followed, e.g. by Vampola (1991), in my opinion the type specimen of Polyporus hibernicus clearly belongs to "the yellow taxon". It is therefore proposed that instead of "the white/cystidiate taxon" $O$. hibernicus is the correct name for "the yellow taxon" of this complex.

The evident reasons for the misapplication of Polyporus hibernicus are the white colour reported in the original description (Berkeley \& Broome 1871) and the few hymenial cystidia in the type (Ryvarden 1974, 1978). Based on these characteristics it is logical to link the name to "the white/cystidiate taxon" instead of "the yellow taxon". However, as shown here and confirmed by field observations in Finland (Niemelä, pers. comm., Niemelä 2005, Fig. 164) "the yellow taxon" is often pure white when young and fresh, and turns yellow by age. The revision here of the types and other materials further showed that hymenial cystidia can be found in all of the four species of the complex. Both macroscopical and microscopical characteristics of the holotype of $O$. hibernicus fit to "the yellow taxon". This is e.g. the case with the spore shape and size, the hyphal characteristics and the habit and scantiness of hymenial cystidia.

Accordingly, the name Oligoporus septentrionalis (Vampola 1991) is proposed to be reduced as a heterotypic synonym of $O$. hibernicus, and the name Oligoporus parvus Renvall is proposed below for the undescribed "white/cystidiate taxon" earlier erroneously called as O. hibernicus or Postia hibernica in northwestern Europe.

Oligoporus perdelicatus (Murrill) Gilb. \& Ryvarden

While revising the Finnish herbarium materials identified as Oligoporus hibernicus s. lat. it became evident that in addition to the two earlier recognized taxa, viz. "the yellow taxon" $O$. hibernicus sensu typi and "the white/cystidiate taxon" O. parvus n. sp., still another white and cystidia-bearing taxon had been collected from seven localities in eastern Finland.

The specimens of this third species (hereafter "narrow-spored taxon") had narrower (mostly 1.1-1.4 $\mu \mathrm{m}$ wide) spores than those in Oligoporus parvus (mostly 1.6-2.0 $\mu \mathrm{m}$ wide). In addition, the cystidia were generally more abun- 
dant than in $O$. parvus. Because of these characteristics a name for this taxon was searched in the vicinity of $O$. simanii (Pilát) Bernicchia, whose spores are the narrowest in this group. $O$. simanii sensu typi however, has only $0.8-1.2 \mu \mathrm{m}$ wide spores, and they are shorter than found in the Nordic specimens.

A name for this "narrow-spored taxon" was found in Lowe's (1975) revision of the North American tyromycetoid polypores. The description of Oligoporus perdelicatus (as Tyromyces perdelicatus Murrill) given in the paper accorded well with the Finnish specimens, and the examination of the holotype (NY) confirmed that "the narrow-spored taxon" in the Finnish material belongs to $O$. perdelicatus. Accordingly the species is here reported as a new species to Europe.

In the original description Murrill (1912) stated that the species bears hymenial cystidia, but Overholts (1953) as well as Gilbertson and Ryvarden (1987) could not confirm their presence. Hymenial hyphoid cystidia are abundant, however, in both the type and in the Finnish collections. They are similar to those of $O$. parvus, although more numerous.

\section{Polyporus subsericeomollis Romell}

The identity of Polyporus subsericeomollis has been discussed e.g., by Kotlaba and Pouzar (1964), Donk (1972) and Ryvarden (1974). A note is presented here, because some authors have linked this name with the species of the Oligoporus hibernicus group. The misconcept is evidently based on the careless and partly erroneous (see Donk 1972) original description of Romell (1926) Another reason why this taxon is treated here is that the holotype of Polyporus subsericeomollis is an illustration.

I follow the interpretations of Kotlaba and Pouzar (1964) and Donk (1972, 1974) that the holotype of Polyporus subsericeomollis (photograph 1571 in Svensk Bot. Tidskrift 6:643) illustrates Oligoporus floriformis (Quélet) Gilb. \& Ryvarden, e.g. with well-developed caps. On the basis of the photograph number (1571) it can even be traced that the photograph refers to the particular specimen of $O$. floriformis collected in the Kaknäs forest in Stockholm on Picea stump in 1912 (S 12617; originally identified as Polyporus sericeomollis? by Romell; studied). The number of the photograph has been typed on the

label of this specimen, and Romell himself connected this collection to the photograph 1571 in his notebook (in S; Dr. Åke Strid in litt.).

\section{Species descriptions}

Oligoporus hibernicus (Berk. \& Broome) Gilb. \& Ryvarden sensu typi-Figs. 1, 2

Polyporus hibernicus Berk. \& Broome, Ann. Mag. Nat. Hist. Ser. 4, 7: 428, 1871. Holotype: Ireland. Luggela: Wicklow, on Pinus, IX.1867 Herb. Berk. 1879 (K, studied).

Oligoporus septentrionalis Vampola.

Physisporus flavicans P. Karst. sensu Romell, non sensu typi (= Junghuhnia luteoalba).

Poria johnstonii Murrill sensu Ryvarden (1974), non sensu typi (= Diplomitoporus lindbladii (Berk.) Gilb. \& Ryvarden).

Basidiocarps annual, resupinate, thin (up to 6 $\mathrm{mm}$ thick), usually gregarious with a few small, irregular patches (1-3 cm long) but may grow up to $15 \mathrm{~cm}$ wide, soft and fragile when fresh, fragile when dry. Pore surface pure white to pale citric yellow when young and fresh, pale yellow when old, young basidiocarps turning yellow, and older basidiopcarps evidently to more deep yellow or straw-coloured when dry (the yellow colour of pores depends on the amount of yellow crystal mass in trama), often with small (1-3

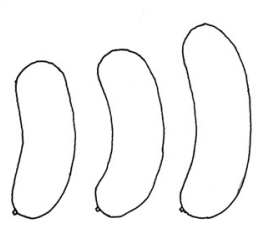

a

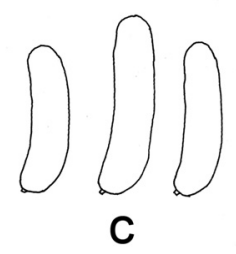

Fig. 1 Basidiospores of a) Oligoporus hibernicus (Berk. \& Broome) Gilb. \& Ryvarden (from the holotype), b) $O$. parvus Renvall (from the holotype), c) O. perdelicatus (Murrill) Gilb. \& Ryvarden (from the holotype), d) O. simanii (Pilát) Bernicchia (from the holotype). 
$\mathrm{mm}$ in diam), circular depressions. Pores circular to angular, more irregular when old, 3-4(-5) per $\mathrm{mm}$, close to margin often smaller, when dry walls very thin; tube mouths finely tomentose, may become lacerate with age. Sterile margin narrow (often less than $0.5 \mathrm{~mm}$ wide) but usually distinct, entire, cottony and permanently white (often contrasting to the yellow or straw-coloured tubes). Section: Subiculum very thin, usually less than $0.5 \mathrm{~mm}$ thick, white to cream, soft when fresh, fragile when dry. Tubes concolorous with the pore surface, usually only $0.5-3 \mathrm{~mm}$ long.

Monomitic, all hyphae hyaline, IKI- and CB-. Generative hyphae in subiculum thin- to somewhat thick-walled, usually richly branched,
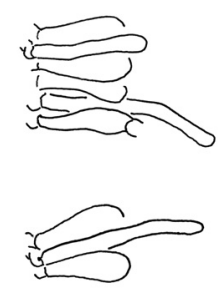

a
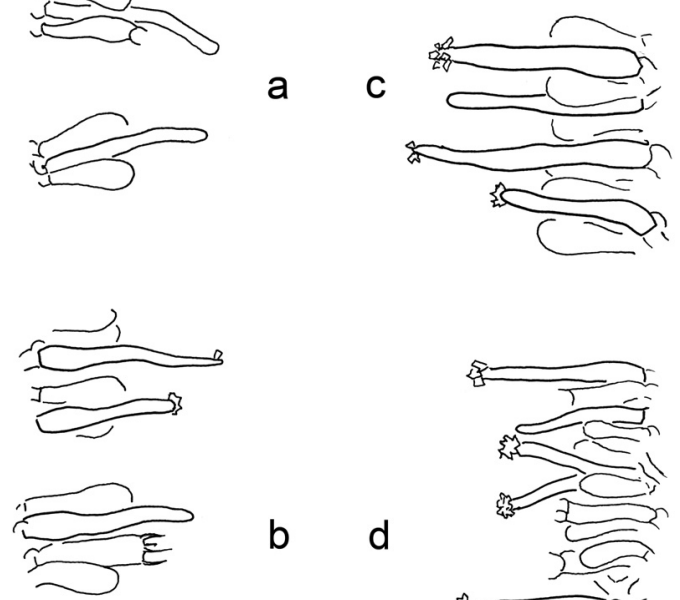

b

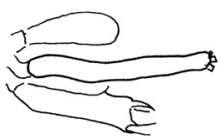

$15 \mu \mathrm{m}$
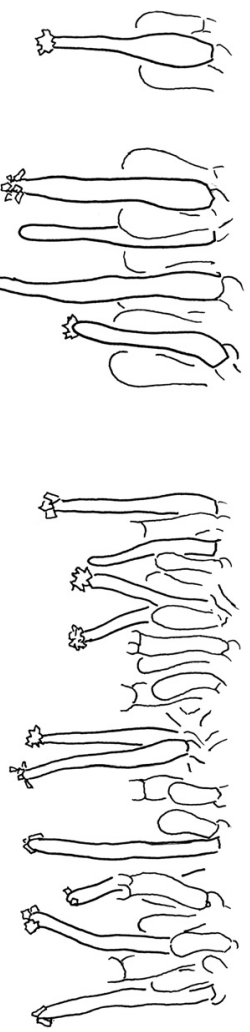

Fig. 2. Hymenial cystidia of a) Oligoporus hibernicus (Berk. \& Broome) Gilb. \& Ryvarden, the upper from the type, the lower from the holotype of Oligoporus septentrionalis Vampola, b) O. parvus Renvall (from the holotype), c) O. perdelicatus (Murrill) Gilb. \& Ryvarden (from the holotype), d) O. simanii (Pilát) Bernicchia (from the holotype). with frequent cross-walls and clamp connections, 2.5-4 $\mu \mathrm{m}$ wide, crystals abundant among the hyphae, some hyphae decorated with crystal rosettes, a few of them with oily content. Tramal hyphae winding, somewhat intermixed to subparallel, rarely to moderately branched, $2-4 \mu \mathrm{m}$ wide, a few of them with oily content, abundant yellow crystal mass often present among the hyphae, hyphal tips at the dissepiment edges often charateristically somewhat inflated (inflated hyphal tips up to $6 \mu \mathrm{m}$ thick). Subhymenium often distinct. Hyphal pegs abundant. Basidia mostly slender-based and narrowly clavate, with a basal clamp, with four sterigmata, 15-24.5 × 3.5-5.5 $\mu \mathrm{m}$. Basidioles slightly smaller. Cystidia almost always absent, but in some specimens (e.g., in the type of Oligoporus septentrionalis and in the type of Polyporus hibernicus thin-walled hyphoid cystidia rarely present, evidently always without proper apical crystal crown, 13-21 × 2-3 $\mu \mathrm{m}$. Basidiospores narrowly cylindric, mostly evenly curved, thin-walled, smooth, hyaline, IKI- and CB-, apiculus often very small, (4.0-)4.3-5.8 $(-6.2) \times(1.3-) 1.4-1.9(-2.0) \mu \mathrm{m}, \mathrm{L}=5.0 \mu \mathrm{m}$, $\mathrm{W}=1.7 \mu \mathrm{m}, \mathrm{Q}=2.6-3.1(\mathrm{n}=212 / 5)$.

Specimens examined: Finland. Uusimaa: Helsinki 1994 Saarenoksa 28594 (H), Lohja 1994 Järveläinen 234 (HT.N.), Tammisaari 1967 Laine et al (HFR, H.K.), Vantaa 1995 Saarenoksa 20695 (H, KUO, H.K.). Etelä-Savo: Ruokolahti 1964 Laine \& Poutanen (HFR, H.K.). Pohjois-Häme: Kuru 1986 Penttilä 240, 476, 477 (R.P.), Parkano 1996 Penttilä 11349, 11352, 11366 (KUO, R.P.), 1997 Penttilä 11491 (KUO), 11511 (KUO), Ruovesi 1996 Penttilä 11279 (KUO, R.P.), Saarijärvi 1984 Kotiranta 5418 (H.K.). Pohjois-Karjala: Lieksa 1989 Penttilä 1399 (R.P.), 1798 (R.P.). Kainuu: Suomussalmi 1992 Penttilä 3920 (R.P.), 1996 Penttilä 11285, 11290 (R.P.). Oulun Pohjanmaa: Oulu 2001 Kulju 87/01 \& Halonen, Kulju 243/01 \& Halonen (KUO), Kulju 236/01 \& Hanhimäki (OULU), Halonen \& Hanhimäki (2 specimens OULU, KUO), Halonen (OULU, KUO). Perä-Pohjanmaa: Rovaniemi comm. 1981 Kotiranta 3519 (H.K.), Tervola 1981 Kotiranta 3615 (H.K.). Koillismaa: Kuusamo 1984 Kotiranta 5547 (H.K.). Norway. Akershus: Bærum 1976 Nakken (O). Oslo 1909-1913 Egeland (11 specimens in O), 1909-1913 Egeland (4 specimens in S), 1911 Egeland (GB-J.E.). Hordaland: Voss herred 1950 Stordal 3901 (O), 1951 Stordal, B. \& J. Eriksson 6149 (GB-J.E., O, UPS as Polyporus subsericeomollis), 6254 (GB-J.E. as P. subsericeomollis). Buskerud: Kongsberg 1978 G.M.J. (O-L.R.), Nes 1989 Ryvarden 27154 (O-L.R.). Oppland: Sør-Aurdal 1971 Ryvarden 8115 (O-L.R.). Hedmark: Kongsvinger 1985 G.M.J. 416/85 (O-L.R.), Løten 1982 Aanstad 1189 (O-L.R.). Sør-Trøndelag: Oppdal 1980 Hjortstam 11594 (GB-J.E.), Trondheim: 1951 B. \& J. Eriksson 5704 (TRH, UPS). Nordland: Rana 1976 Hereng 275 (O). Slovakia. Sub cacumine montis "Patria" 
(in ca 1100 m s.m) ap. Spišské Podhradie, montes Branisko, Slov. or. 1970 Kotlaba (Holotype of Oligoporus septentrionalis Vampola, PRM 842858). Sweden. Södermanland: Bedarö 1910 Romell (S 13187), Saltsjö-Duvnäs 1916 Romell (S 13192), Södertörn 1922 Romell (S 13256), Ytterstjärna 1912 Romell (S 13895). Uppland: Bromma 1912 Romell (S 13190, 13790, 13791, 13829, 13830, 13896), 1913 Romell (S 13191), DjursholmsDanderyd 1908 Romell (S 12827, 13186), 1912 Romell (S 12619, 13831), Stockholm 1908 Romell (S 12612), 1913 Romell (S 13897), 1921 Romell (S 13259). Dalarna: Svärdsjö 1974 Morander 1942 (GB). Hälsingland: Hassela 1966 Eriksson (GB).

Ecology and distribution: Oligoporus hibernicus sensu typi causes brown rot on dead conifers, such as Picea abies and Pinus sylvestris. Most of the collections derive from decorticated logs of spruce. The species is here reported from Finland, Ireland, Norway, Slovakia and Sweden. On the basis of the present study it is evident that in Europe most of the earlier records of O. septentrionalis deal with this species. In Finland $O$. hibernicus has clearly more southern and western distribution than $O$. parvus.

Oligoporus hibernicus has also been reported from North America (e.g. Gilbertson \& Ryvarden 1987, Boulet 2003) but this study implies that most of those records refer to $O$. perdelicatus. This may also be the case with some collections in South and Central Europe.

\section{Oligoporus parvus Renvall, species nova}

- Figs. 1, 2

Fungus lignum putrescens, carpophorum annuum, effusum vel effuso-reflexum, parvum, tenue, in vivo molle, in sicco fragile, pileus supra albus - cinerascens, pori superficie albi, 3-4 pro mm. Systema hypharum monomiticum, hyphae hyalinae, sporae hyalinae, cylindricae, 5.3-7.1 $\times 1.6-2.0 \mu \mathrm{m}$.

Holotype: Finland. Kainuu: Suomussalmi, Hossa, Moilasenvaara (Grid $27^{\circ}$ E: 72625:6046), fallen, decorticated kelo trunk of Pinus sylvestris, 17.IX.1998 Kaisa Junninen 955 (KUO).

Basidiocarps annual, resupinate or effused-reflexed with a narrow fingernail-like pileus elongated along the upper margin; very small and thin (usually only $0.5-1 \mathrm{~mm}$ thick), often gregarious with a few small and irregular patches, soft and fragile when fresh, fragile when dry, resupinate areas irregular, remaining often small $(0.5 \times 1 \mathrm{~cm})$, occasionally up to $3 \times 6 \mathrm{~cm}$. Pilei, if present, thin and flattening easily down under slightest pressure, with a blunt or fairly sharp margin, $0.2-2(-5) \mathrm{cm}$ wide, projecting only $1-2$ $\mathrm{mm}$ (occasionally up to $7 \mathrm{~mm}$ ) from substrate. Upper surface soft, cottony and azonate, when young pure white to cream-coloured, when mature often with a faint greyish tint. Sterile margin finely pubescent, white, very narrow, often less than $0.5 \mathrm{~mm}$ wide. Pore surface white when fresh, turning cream when dry; pores circular to angular, more irregular and partly split when old, variable in size, $(2-) 3-4(-5)$ per $\mathrm{mm}$, walls thin; tube mouths finely tomentose, becoming lacerate with age. Section: Context white to cream, very thin, usually only $0.2-0.5 \mathrm{~mm}$ thick, soft when fresh, fragile when dry. Tubes concolorous with the pore surface, $0.5-1(-2) \mathrm{mm}$ long.

Monomitic, all hyphae hyaline, thin-walled, IKI- and CB-. Generative hyphae in subiculum (context) moderately branched and with frequent cross-walls and clamp connections, 2.5-4 $\mu \mathrm{m}$ wide, in subiculum loosely interwoven and then without clear orientation or horizontally subparallel, no distinct basal layer. Tramal hyphae subparallel, rarely interwoven, winding, moderately to rarely branched, $2-3.5(-4) \mu \mathrm{m}$ wide, a few of them with oily content. Subhymenium indistinct. Hyphal pegs variably present. Basidia slenderbased, narrowly clavate, with a basal clamp, with four long sterigmata, (13-)13.5-21(-27) $\times(3.5-) 4-5.5(-6) \mu \mathrm{m}(\mathrm{n}=75 / 10)$. Basidioles slightly shorter, similar in shape. Hymenial cystidia present, usually rare (and then difficult to find) sometimes locally more frequent, narrowly obclavate with a finger-like apex to hyphoid, usually somewhat projecting, thin-walled, smooth or with a small apical crystal crown, (15-)18-30($31) \times 3-5(-5.5) \mu \mathrm{m}(\mathrm{n}=50 / 5)$. Basidiospores cylindrical, often slightly curved near apiculus, thin-walled, smooth, hyaline, IKI- and CB-, (5.1-)5.3-7.1(-8.0) × (1.4-)1.6-2.0 $\mu \mathrm{m}, \mathrm{L}=6.1$ $\mu \mathrm{m}, \mathrm{W}=1.8 \mu \mathrm{m}, \mathrm{Q}=3.1-3.9(\mathrm{n}=430 / 16$ specimens from Finland).

Etymology: parvus (Lat., adj.), referring to the very small basidiocarp size.

Specimens examined: Finland. Pohjois-Häme: Saarijärvi 1981 Kotiranta 3742 (H.K.). Pohjois-Karjala: Ilomantsi 1984 Kotiranta 5740 (H.K.), 1994 Junninen 154 (H), Lieksa 1988 Penttilä 1022 (H, H-T.N., R.P.). Kainuu: Puolanka 2000 Laitinen 592 (KUO), Suomussalmi 1998 Junninen 955 (Holotype KUO), 959 (KUO). Perä-Pohjanmaa: Pudasjärvi 1992 Penttilä 3786, 3849 (R.P.), Rovaniemi comm. 1960 Kujala \& Eriksson 9743 (GB-J.E.), 1982 Kotiranta 4174 (H.K.), 1992 Kotiranta 
10839 (H.K.) Koillismaa: Kuusamo 1978 Johansen \& Ryvarden 17319 (O), 1995 Vehmaa 756 (H, H.K.), 763 (H, H.K.), 2000 Laitinen 642, 657 (KUO). Salla 1987 P. Renvall 474a, 475, 480, 481, 483, $582(\mathrm{H}), 1988$ P. Renvall 1064, 1227, 1334, 1357, 1378, 1393, 1397, T. Renvall 321, 382a, $383(\mathrm{H}), 1992$ P. Renvall $2842(\mathrm{H}), 3039(\mathrm{H}$, HUBO), 3048 (KUO), 3051 (KUO), 3057 (KUO), 3060c (KUO). Kittilän Lappi: Kittilä 1960 Kujala \& Eriksson 9937 (GB-J.E., O), 1982 Kotiranta 4111 (H.K.). Sompion Lappi: Savukoski 1993 P. Renvall 3319 \& Turunen (H), Sodankylä 1992 P. Renvall 2842 (KUO), 2817 (KUO), 1993 P. Renvall 3319 (KUO). Inarin Lappi: Inari 1990 Kotiranta 8514 (H.K.), 2001 Kulju 143/01 (KUO). Norway. Hordaland: Granvin 1951 Eriksson 6060 (GB-J.E.). Nordland: Hamarøy 1975 Bjørgum (O-L.R.), 1976 Bjørgum (O-L.R.). Buskerud: Hønefoss 1977 Ryvarden 14575 (O). Akershus: Frogn 1974 Johansen (O-L.R.). Sogn og Fjordane: Luster 1978 Støverud 67+78 (O). Oppland: Dovre 1979 Ryvarden (O-L.R.). Hedmark: Engendal 1992 Ryvarden 31957 (O-L.R.), Løten 1978 Høgholen 1287/78 (O-L.R.). Sweden. Småland: Rumskulla 1987 Andersson 151 (GB). Södermanland: Nacka 1906 Romell (S 12610), Österhaninge 1991 Toresson (S). Värmland: Dalby 1984 Owe-Larsson 3043 (UPS), Torsby 1994 Jansson (H). Upland: Bromma 1912 Romell (S 13789, 13788, as Polyporus sericeomollis Romell). Stockholm 1896 Romell (S, S 12605), 1912 Romell (GB, S), 1917 Romell (S 13802, 13868), Lena 1926 Lundell (S 12622), Lidingö 1908 Romell (S 12615), Upsala 1905 Fries (S 12623), Ärentuna 1926 Lundell (S). Dalarna: Idre 1944 Eriksson 23233 (GB-J.E.). Lule Lappmark: Gällivare 1948 Eriksson 3145 (GB), 3210 (GB).

Ecology and distribution. Oligoporus parvus is a fairly rare boreal species found in dry coniferous forests of Finland, Sweden and Norway. In Finland most of the collections derive from the Northern Boreal zone (as delimited by Ahti et al. 1968), and it has more eastern and northern distribution than $O$. hibernicus. In northwestern Europe most of the earlier records of O. hibernicus auct. (incl. Postia hibernica and Tyromyces subsericeomollis auct.), e.g., those reported by Renvall (1995) and Sippola and Renvall (1999) deal with this species. This is evidently also the case with many records from Russia (e.g. Hermansson 1997, Bondartseva 1998). However, in addition to $O$. parvus, the herbarium specimens filed under these names and revised in this study included several other taxa: $O$. hibernicus sensu typi, O. leucomallellus (Murrill) Gilb. \& Ryvarden, O. perdelicatus and Ceriporiopsis subvermispora (Pilát) Gilb. \& Ryvarden.

In Finland Oligoporus parvus is in general rare, but in northern parts of the country in old pine forests with plenty of decomposing wood there are locally abundant populations left. This is a saprotrophic fungus, which causes a slowly proceeding brown rot on dead wood. Unlike $O$. hibernicus sensu typi, which mostly grows on Picea, O. parvus has been almost exclusively collected on fallen kelo (see Renvall 1995, Niemelä et al. 2002) trunks or branches of Pinus sylvestris, and mostly in old-growth or near-climax pine forests. On the other hand, O. parvus is also able to invade appropriate logging waste (Sippola \& Renvall 1999) thus showing a rather wide ecological tolerance.

\section{Oligoporus perdelicatus (Murrill)}

Gilb. \& Ryvarden - Figs. 1, 2

Tyromyces perdelicatus Murrill, Mycologia 4:95, 1912. Holotype: U.S.A. Washington: Seattle, on Tsuga heterophylla, 20.XI.1911 Murrill (NY, studied).

Basidiocarps annual, pileate to effused-reflexed or seldom totally resupinate, usually with a narrow elongated pileus along the upper margin; very small and thin (usually only $1-3 \mathrm{~mm}$ thick), solitary or gregarious with a few caps, soft and fragile when fresh, fairly hard but easily crumbling when dry, resupinate areas irregular, often remaining small (up to $0.5 \times 1 \mathrm{~cm}$ ). Pilei thin with a blunt or fairly sharp, somewhat inrolling edge, 2-10(30) $\mathrm{mm}$ wide, projecting 1-3(-7) $\mathrm{mm}$ from substrate. Upper surface soft, tomentose and azonate, pure white when fresh, more cream-coloured when dried, may turn glabrous and partly yellowish with age, minutely wrinkled (seen under lens) when dry. Sterile margin finely pubescent, white, very narrow, often less than 0.5 $\mathrm{mm}$ wide. Pore surface white when fresh, turning cream or somewhat yellowish when dry; pores circular to angular, sometimes sinuose, more irregular and partly split when old, 4-6 per mm, walls fairly thick (somewhat thicker than in $O$. parvus); tube mouths finely tomentose, may become lacerate with age. Section: Context white to cream, very thin, usually up to $0.5 \mathrm{~mm}$ thick, soft when fresh, fragile when dry. Tubes concolorous with the pore surface, $0.5-1(-2) \mathrm{mm}$ long.

Monomitic, all hyphae with frequent crosswalls and clamp connections, hyaline, $\mathrm{CB}-$-, IKIbut golden yellow to slightly reddish (en masse) in IKI. Generative hyphae in subiculum (context) moderately branched, thin-walled, often with short refractive side branches, $2-4(-5) \mu \mathrm{m}$ wide $(\mathrm{n}=75 / 5)$, interwoven and fairly densely packed, mostly naked but a few covered with separate 
crystal rosettes or with very fine granular encrustation, at pileal surface partly collapsed and somewhat densely packed. Tramal hyphae thinto somewhat thick-walled, interwoven to subparallel, winding, moderately branched, (1.5-) $2-3(-3.5) \mu \mathrm{m}$ wide $(\mathrm{n}=83 / 5)$. Subhymenium often distinct. Hyphal pegs irregularly present. Basidia usually slender-based and clavate, with a basal clamp and four sterigmata, (11.5-)12-19 $\times$ 4-5.5 $\mu \mathrm{m}(\mathrm{n}=40 / 3)$. Basidioles slightly shorter, similar in shape. Hymenial cystidia numerous and easy to find (esp. at tube bottoms), mostly hyphoid and somewhat thick-walled, projecting, usually with a small apical crystal crown, rarely smooth (12-)13-35(-40) × (2.5-)3-4.5(-5) $\mu \mathrm{m}$ $(n=40 / 4)$. Basidiospores narrowly cylindric to almost allantoid, thin-walled, smooth, hyaline, IKI- and CB-, (4.5-)4.8-5.7(-6.2) $\times(1.0-) 1.1-$ 1.4(-1.5) $\mu \mathrm{m}, \mathrm{L}=5.2 \mu \mathrm{m}, \mathrm{W}=1.3 \mu \mathrm{m}, \mathrm{Q}=4.0$ $4.4(n=185 / 5$ specimens from Finland $)$.

Specimens examined: Canada. British Columbia: Mc Leod Lake District 1969, Abies lasiocarpa, B. \& J. Eriksson 12621 (GB-J.E. as Tyromyces subsericeomollis), Vancouver Island, Pseudotsuga menziesii 12.IX.1967 B. \& J. Eriksson 7944 (GB-J.E., 2 specimens with the same number; as Tyromyces subsericeomollis). Finland. Pohjois-Karjala: Lieksa, Patvinsuo Nat. Park, Lahnasuo, Pinus sylvestris, 25.IX.1988 Penttilä 1041 (H-T.N.), Rauvunvaara, Pinus sylvestris, 29.IX.1989 Penttilä 1425 (H-T.N.), Suomunjärvi W, Pinus sylvestris, 30.IX.1989 Penttilä 1450 (R.P.). Kainuu: Kuhmo, Laamasenvaara, Picea abies, 9.IX.1998 Junninen 880 (KUO), Suomussalmi, Hossa, Moilasenvaara, Pinus sylvestris, 16.IX.1998 Junninen 943 (KUO), 27.IX.1998 Junninen 1070 (KUO). Koillismaa: Kuusamo, Oulanka Nat. Park, Ampumavaara, Pinus sylvestris, 21.VIII.1988 Kotiranta 7076 (H.K.), Korvasvaara, Kotilaisenlampi N, Pinus sylvestris, 19.IX.1997 Niemelä 6148 \& Dai (H, KUO).

Ecology and distribution. Oligoporus perdelicatus causes brown rot on dead conifers. The European collections derive from old-growth or near-climax pine forests of eastern Finland. All but one of them derive from fallen kelo trunks of Pinus sylvestris and one was collected from fallen, decorticated trunk of Picea abies. Based on the Finnish material it seems that $O$. perdelicatus favours more humid climatical conditions than $O$. parvus.

It is possible that most of the North American collections under the name $O$. hibernicus belong to $O$. perdelicatus. This may also be the case with some southern and central European collections of both $O$. hibernicus auct. and $O$. simanii. It is therefore probable that $O$. perdelicatus is more widely distributed than earlier believed, not only in North America but also in Eurasia. However, the specimens of Oligoporus perdelicatus (as Postia perdelicata (Murr.) M.J. Larsen \& Lombard; studied) reported from Alaska by Volk et al. (1994) from deciduous wood belong to other taxa.

\section{Oligoporus simanii (Pilát) Bernicchia}

- Figs. 1, 2

Leptoporus simanii Pilát, Atl. Champ. Europ. 3:181, 1938. Holotype: Ukraine, Zakarpats'ka Oblast, Zamer prope Kobylecká Polana, Fagus sylvatica VII.1929 Pilát (PRM 497732, studied; isotype in S)

Basidiocarps annual, resupinate and very thin, usually only $1 \mathrm{~mm}$ thick, remaining often very small, soft and brittle when dry. Sterile margin distinct, finely floccose, permanently white, 0.5 $1 \mathrm{~mm}$ wide. Pore surface white when young and fresh, turning pale cream to straw-coloured with age and when dry; pores circular to angular, very small, (4-)6-8 per mm, tube mouths finely fimbriate. Section: Subiculum (context) very thin, up to $0.3 \mathrm{~mm}$ thick, basal layer permanently white, very thin (up to $0.1 \mathrm{~mm}$ thick), medullary layer dense, straw-coloured, concolorous with tubes, up to $0.2 \mathrm{~mm}$ thick. Tubes concolorous with the pore surface, up to $1 \mathrm{~mm}$ long, hymenial cystidia numerous and seen well under the lens $(\times 50)$.

Monomitic, all hyphae with frequent crosswalls and clamp connections, hyaline, $\mathrm{CB}-$ and IKI-. Basal layer made up of loosely interwoven, moderately branched, thin- to somewhat thick-walled generative hyphae, medullary layer dense, made up of tightly interwoven generative hyphae; sinuous and richly short-branched generative hyphae (resembling binding hyphae) abundant in medullary layer and in trama. Tramal hyphae mostly thin-walled and moderately to tightly interwoven, winding, moderately to richly branched. Subhymenium indistinct. Hyphal pegs abundant. Basidia slender-based and clavate, with a basal clamp and four sterigmata, $10.5-15 \times 3-4 \mu \mathrm{m}(\mathrm{n}=20 / 1)$. Basidioles shorter and narrower 6-11 × 2.5-3.5 $\mu \mathrm{m}(\mathrm{n}=24 / 1)$, similar in shape. Hymenial cystidia numerous and easy to find, hyphoid, mostly somewhat thickwalled, projecting, with an apical crystal crown (easily dissolving in $\mathrm{KOH}$ ), $18-30 \times 2.5-3 \mu \mathrm{m}$ 
( $n=21 / 1)$. Basidiospores narrowly allantoid, thin-walled, smooth, hyaline, IKI-, CB-, (3.9-) $4.0-5.3(-5.6) \times 0.8-1.2 \mu \mathrm{m}, \mathrm{L}=4.4 \mu \mathrm{m}, \mathrm{W}=1.0$ $\mu \mathrm{m}(\mathrm{n}=115 / 3)$.

Specimens examined: Iran. Mazanderan 1976, L. \& N. Hallenberg 1957 \& D. Ershad (GB-J.E.) Italy. Bosco de Cansiglio, Plan della Stelle (Pordeno), Sorbus aucuparia 1987 Bernicchia 4704 (HUBO).

Ecology and distribution. The holotype of Oligoporus simanii was collected on brown-rotted Fagus sylvatica in Ukraine. Grosse-Brauckmann (1980) found the species on a fallen twig of Acer pseudoplatanus and a leaf of Fagus sylvatica lying nearby from Germany. This seems to be the only species in the O. hibernicus complex that grows on deciduous trees in Europe. Tortic (1992), Ryvarden \& Gilbertson (1994) and Bernicchia (2005) include also some conifers in the host tree list, but I feel that further studies are needed to reveal the morphological variation and species limits of $O$. simanii, concerning, in particular, the specimens collected on conifers. Therefore the description above is based solely on the the holotype and two other specimens collected on deciduous trees.

Oligoporus simanii has a southern distribution in Europe. It has also been reported from North America (Gilbertson \& Lowe 1961, Lowe \& Gilbertson 1962), but Ryvarden \& Gilbertson (1987) treated it collectively with $O$. hibernicus. It may well be that some earlier records of both $O$. hibernicus and $O$. simanii in fact deal with $O$. perdelicatus. More material should be collected and studied to reveal the real situation of all these taxa in North America.

\section{Identification}

Although the European species of the Oligoporus hibernicus complex are very similar to the eye and microscopy is needed to verify their identification, there are some macroscopical characteristics that help with the determination. O. parvus and $O$. perdelicatus often produce narrow pilei, while $O$. hibernicus is resupinate. Evidently also $O$. simanii produces mostly resupinate basidiomes. The caps of $O$. parvus are very soft, flattening easily under slightest pressure and often turning greyish with age, while $O$. perdelicatus is more dense, when dry more brittle and crumbling, and remains mostly white to cream.

The species can be also grouped according to the pore size. Oligoporus parvus and O. hibernicus have fairly large pores $(3-4 / \mathrm{mm})$, while the pores of $O$. perdelicatus $(4-6 / \mathrm{mm})$ and $O$. simanii $(6-8 / \mathrm{mm})$ are smaller. Also the colour of the pore surface can help in the identification. The clearly yellow specimens with small craters left from droplets most probably belong to $O$. hibernicus.

In the microscope the basidiospores and hymenial cystidia offer practical tools for identification. In most cases the species can be reliably identified on the basis of the spore size (Table 1) and shape (Fig. 1). The spores of O. hibernicus are mostly slightly and evenly curved, while those of $O$. parvus are often curved just above the apiculus, but otherwise fairly straight (Fig. 1 ). The spores of $O$. perdelicatus and $O$. simanii are narrowly allantoid and more or less evenly curved. The spore size, however, should always be measured, and because of the small differenc-

Table 1. Basidiospore size (in $\mu \mathrm{m}$ ) in different herbarium materials of the Oligoporus hibernicus (Berk. \& Broome) Gilb. \& Ryvarden complex. L = mean length, $\mathrm{W}=$ mean width, $\mathrm{Q}=$ length/width quotient, $\mathrm{n}=$ number or spores measured/number of specimens.

\begin{tabular}{llllll}
\hline & & $\mathrm{L}$ & $\mathrm{W}$ & $\mathrm{Q}$ & $\mathrm{n}$ \\
\hline O. hibernicus type & $(4.0-) 4.2-5.7(-6.2) \times 1.3-1.8$ & 4.9 & 1.6 & 3.1 & $70 / 1$ \\
O. septentrionalis type & $(4.0-) 4.1-5.2(-5.3) \times(1.5-) 1.6-1.8$ & 4.7 & 1.8 & 2.6 & $50 / 1$ \\
O. parvus sp. nova/Finland & $(5.1-) 5.3-7.1(-8.0) \times(1.4-) 1.6-2.0$ & 6.1 & 1.8 & $3.1-3.9$ & $430 / 16$ \\
O.perdelicatus type & $(4.0-) 4.2-5.2(-5.3) \times 1.0-1.3$ & 4.7 & 1.1 & 4.1 & $50 / 1$ \\
O. perdelicatus/Finland & $(4.5-) 4.8-5.7(-6.2) \times(1.0-) 1.1-1.4(-1.5)$ & 5.2 & 1.3 & $4.0-4.4$ & $185 / 5$ \\
O. simanii type & $(3.9-) 4.0-4.4(-4.5) \times 0.8-1.1$ & 4.2 & 1.0 & 4.4 & $55 / 1$ \\
\hline
\end{tabular}


es preferably in a viscid mountant such as Cotton Blue. O. parvus has the largest $(5.3-7.1 \times 1.6-$ $2.0 \mu \mathrm{m}$ ) spores. O. simanii has narrower (mostly $<1.2 \mu \mathrm{m}$ ) and shorter (mostly $<5 \mu \mathrm{m}$ ) spores than found in the other species. Also O. perdelicatus has narrow spores, but they are somewhat wider and longer $(4.8-5.7 \times 1.1-1.4 \mu \mathrm{m})$ than in $\mathrm{O}$. simanii.

Some hyphal characteristics help with the determination, too. Unlike in the other species, the tramal hyphae in Oligoporus simanii are more tightly interwoven and more winding. In addition, richly short-branched generative hyphae (resembling binding hyphae) are abundant in both medullary layer and in trama. In $O$. hibernicus the hyphal tips at the dissepiment edges are usually distinctly inflated. This seems to be a fairly reliable characteristic, although I have seen somewhat enlarged hyphal tips in some specimens of $O$. parvus, too.

The presence/absence of hymenial cystidia has traditionally been regarded as one of the key characteristics in this complex of species, which is one of the main reasons for the taxonomical and nomenclatural confusions. Earlier it was generally believed that cystidia are totally absent in "the yellow taxon" O. hibernicus sensu typi (= $O$. septentrionalis) and in $O$. perdelicatus. The examination of the present material showed, however, that hyphoid hymenial cystidia are variably found in all these four species (Fig. 2). They are very rare and mostly absent in $O$. hibernicus but, unfortunately, single cystidia can sometimes be found. This is the case e.g. with the holotypes of $O$. hibernicus and O. septentrionalis. Hymenial cystidia are most abundant in $O$. simanii, and can even be detected in the pores already by lens $(x$ 50 ). Also in $O$. perdelicatus they are usually numerous and easy to find in the microscope, while in O. parvus they are rarer and more difficult to find. The cystidia of $O$. hibernicus, if present at all, are thin-walled and mostly naked. In the other species they are slightly thick-walled and decorated by an apical crystal crown, which dissolves easily in $\mathrm{KOH}$. The cystidia of $O$. simanii seem to be somewhat narrower $(18-30 \times 2.5-3$ $\mu \mathrm{m}$ in the type) but more thick-walled than those of $O$. parvus and $O$. perdelicatus.

In addition to the above-listed, some other species of Oligoporus (and Postia) should be taken into account when the taxonomy of these taxa is discussed and the specimens are identi- fied. Oligoporus inocybe is a Mediterranean species, mostly collected on coniferous trees (Ryvarden \& Gilbertson 1994). By eye it reminds a lot all the species of the O. hibernicus complex, and it is very similar also in the microscope. The mostly thick-walled pyriform to broadly clavate hymenial cystidia are diagnostic (see, e.g. Pieri \& Rivoire 1998, Bernicchia 2005).

Further members of the Oligoporus hibernicus complex are found in South America. Postia minuta, recently described from the Patagonian Andes of southern Argentina by Rajchenberg (2001), exhibits many characteristics resembling those of $O$. perdelicatus. However, it grows on deciduous tree, its pores are larger, it lacks cystidia, and the hyphae are often thick-walled. Postia venata is another related species (Rajchenberg 1983). Its spores are very narrow, almost identical to those of Oligoporus simanii, but it is a distinctly pileate fungus with hairy caps that are overrun by beautiful bluish-blackish veins.

\section{Acknowledgements:}

I am grateful to Dr. Tuomo Niemelä (Helsinki) for the valuable discussions on the $O$. hibernicus complex and, in particular, for the help with $O$. perdelicatus, as well as for the notes and improvements on the manuscript. Prof. Teuvo Ahti helped with the Latin description. The curators of the herbaria GB, H, K, KUO, NY, O, PRM, S and UPS are thanked for arranging the loans of the type specimens and other collections. Prof. Åke Strid (S) is thanked for the help and comments (in litt.) on the type material of Polyporus subsericeomollis. Dr. Heikki Kotiranta, Dr. Tuomo Niemelä, Dr. Reijo Penttilä (all from Helsinki) and Prof. Leif Ryvarden (Oslo) generously placed their personal collections at my disposal. Prof. Nils Hallenberg (Göteborg) is thanked for arranging the loan from GBJ.E. Dr. Annarosa Bernicchia (Bologna) and Dr. Mario Rajchenberg (Chubut) are thanked for the valuable specimen exchange. Jukka Tuononen (Kuopio) gave technical assistance with the figures.

\section{References}

Ahti, T., Hämet-Ahti, L. \& Jalas, J. 1968: Vegetation zones and their sections in northwestern Europe. - Ann. Bot. Fennici 5: 169-211.

Berglund, H. \& Ryvarden, L. 2000: Oligoporus norrlandicus nov. sp. - Cryptogamie Mycol. 21: 145-146.

Berkeley, J.M. \& Broome, C.E. 1871: Notices of British fungi. - Ann. Mag. Nat. Hist. Ser. 4., 7: 425-436.

Bernicchia, A. 1990: Polyporaceae s. 1. in Italia. - 596 pp. Edito a cura dell'Istituto di Patologia Vegetale dell’Universitá degli Studi di Bologna. 
Bernicchia, A. 2005: Polyporaceae s. 1. (Fungi Europaei 10). -808 pp. Edizioni Candusso, Alassio, Italy.

Bondartseva, M.A. 1998: Definitorium Fungorum Rossiae. Ordo Aphyllophorales. Fasc. 2. - 391 pp. Nauka, St. Petersburg.

Boulet, B. 2003: Les champingnons des arbres de l'est de l'Amerique du nord. - 723 pp. Les Publications du Québec, Sainte-Foy.

Donk, M.A. 1960: The generic name proposed for Polyporaceae. - Persoonia 1: 173-302.

Donk, M.A. 1972: Notes on European polypores 10. Proc. Koninkl. Nederl. Akademie van Wetenschappen (C) $75: 165-178$.

Donk, M.A. 1974: Check list of European polypores. Verh. Koninkl. Nederlandsche Akad. Wetensch. Afd. Natuurk., Tweede Reeks 62: 1-469.

Eriksson, J. 1958: Studies in Heterobasidiomycetes and Homobasidiomycetes-Aphyllophorales of Muddus national park in North Sweden. - Symb. Bot. Upsal. 16: $1-172$.

Gilbertson, R.L. \& Lowe, J.L. 1962: Notes on western polypores. - Papers of the Michigan Academy of Science, Arts and Letters 47: 165-179.

Gilbertson, R.L. \& Ryvarden, L. 1985: Some new combinations in the Polyporaceae. - Mycotaxon 22: 363 365.

Gilbertson, R.L. \& Ryvarden, L. 1987: North American polypores 2. Megasporoporia - Wrightoporia. - Pp. 434-885. Fungiflora, Oslo.

Grosse-Brauckmann, H. 1980: Tyromyces simanii (Pil. ex Pil.) Parm., erster Fund aus der Bundesrepublik Deutschland. - Westfäl. Pilzbr. 11: 159-162.

Halonen, P., Kulju, M., Kangas, K. \& Kalleinen, L. 2002: Oulujoen suistoalueen käävät. -42 pp. Oulun yliopiston kasvimuseo.

Hansen, L. \& Knudsen, H. (eds.) 1997: Nordic Macromycetes 3. Heterobasidiod, aphyllophoroid and gastromycetoid Basidiomycetes. - 444 pp. Nordsvamp, Copenhagen.

Hermansson, J. 1997: Polyporaceae s. lat. and some other fungi in Pechoro-Ilych Zapovednik, Russia. - Windahlia 22: 67-79.

Holmgren, P.K. \& Holmgren N. H. 1998: onwards (continuously updated): Index Herbariorum. New York Botanical Garden. http: //sciweb.nybg.org/science2/ IndexHerbariorum.asp

Jülich, W. 1982: Notes on some Basidiomycetes (Aphyllophorales and Heterobasidiomycetes). - Persoonia 11: 421-428.

Kirk, P.M. \& Ansell, A.E. 1992: Authors of fungal names. - Index of Fungi Supplement. 95 pp. CABI International, Oxon.

Kotlaba, F. \& Pouzar, Z. 1964: Tyromyces gloeocystidiatus Kotl. \& Pouz. sp. nov. - A name for an old polypore. - Česká Mykol. 18: 207-218.

Lowe, J.L. 1956: Type studies of the polypores described by Karsten. - Mycologia 48: 99-125.

Lowe, J.L. 1975: Polyporaceae of North America. The genus Tyromyces. - Mycotaxon 2: 1-82.

Lowe, J.L. \& Gilbertson, R.L. 1961: Synopsis of the Polyporaceae of the Western United States and Canada. - Mycologia 53: 474-511.
Lowe, J.L. \& Lundell, S. 1956: The identity of Polyporus trabeus Rostk. - Papers of the Michigan Academy of Science, Arts and Letters 41: 21-24 + Table.

Murrill, W.A.1912: Polyporaceae and Boletaceae of the Pacific Coast. - Mycologia 4: 91-100.

Niemelä, T. 2004: Suomen kääpien määritysopas. (Guide to the polypores of Finland, 15th revised edition). - Helsingin yliopiston kasvitieteen monisteita 184: 1-148.

Niemelä, T. 2005: Käävät, puiden sienet. Polypores, lignicolous fungi. - Norrlinia 13: 1-320. [In Finnish, with English summary]

Niemelä, T. \& Dai, Y.C.: 1999: Luoston käävät. (Polypores of Luosto). - Metsähallituksen luonnonsuojelujulkaisuja A 105: 1-59.

Niemelä, T., Dai, Y.C., Kinnunen, J. \& Schigel, D.S. 2004: New and in North Europe rare polypore species (Basidiomycota) with annual, monomitic basidiocarps. - Karstenia 44: 67-77.

Niemelä, T., Kinnunen, J. \& Kotiranta, H. 2005: Pisavaaran luonnonpuiston ja Korouoman - Jäniskairan suojelualueen käävät. (Polypores of the Pisavaara Strict Nature Reserve and the Korouoma - Jäniskaira Nature Reserve. - Metsähallituksen luonnonsuojelujulkaisuja A 150: 1-51.

Niemelä, T., Wallenius, T. \& Kotiranta, H. 2002: The kelo tree, a vanishing substrate of specified wood-inhabiting fungi. - Polish Bot. J. 47: 91-101.

Overholts, L.O. 1953: The Polyporaceae of the United States, Alaska, and Canada. - 456 pp. Univ. Michigan Press, Ann Arbor.

Pieri, M. \& Rivoire, B. 1998: Postia inocybe (David \& Malencon) Jülich $\mathrm{f}$. Inocybe et f. pileatus, f. nov. Notes nomenclatures sur le genre Postia. - Bull. Soc. Mycol. Fr. 114: 19-33.

Rajchenberg, M. 1983: Basidiomicetos xilófilos de los bosques Andinopatagónicos. Adiciones y correcciones 1. Bol. Soc. Argent. Bot. 22: 41-56.

Rajchenberg, M. 2001: Postia minuta sp. nov. from Southern Argentina. - Harvard Papers in Botany 6: 183-187.

Renvall, P. 1992: Basidiomycetes at the timberline in Lapland 4. Postia lateritia n. sp. and its rust-coloured relatives. - Karstenia 32: 43-60.

Renvall, P. 1995: Community structure and dynamics of wood-rotting Basidiomycetes on decomposing conifer trunks in northern Finland. - Karstenia 35: 1-51.

Renvall, P., Renvall, T. \& Niemelä, T. 1991: Basidiomycetes at the timberline in Lapland 2. An annotated check-list of the polypores of northeastern Finland. - Karstenia 31: 13-28.

Romell, L. 1912: Remarks on some species of the genus Polyporus. - Svensk Botanisk Tidskrift 6: 635-645.

Romell, L. 1926: Remarks on some species of Polyporus. - Svensk Botanisk Tidskrift 20: 1-24.

Ryvarden, L. 1970: New or interesting records of Norwegian polypores 2. - Nytt Mag. Bot. 17: 163-168.

Ryvarden, L. 1974: Type studies in The Polyporaceae 3. Species described by Lars Romell. - Svensk Botanisk Tidskrift 68: 273-284.

Ryvarden, L. 1978: The Polyporaceae of North Europe 2. Inonotus - Tyromyces. - Pp. 215-507. Fungiflora, Oslo. 
Ryvarden, L. 1991: Genera of polypores. Nomenclature and taxonomy. - Synopsis Fungorum 5: 1-363.

Ryvarden, L. \& Gilbertson, R.L. 1994: European polypores 2. Meripilus - Tyromyces. - Synopsis Fungorum 7: 388-743.

Ryvarden, L. \& Stokland, J. \& Larsson, K.-H. 2003: A critical checklist of corticoid and poroid fungi of Norway. - Synopsis Fungorum 17: 1-109.

Sippola, A-L. \& Renvall, P. 1999: Wood-decomposing fungi and seed-tree cutting: A 40-year perspective. - Forest Ecol. Management 115: 183-201.
Tortić, M. 1992: Macromycetes of Gorski Kotor (Croatia) 3. - Acta Bot. Croat. 52: 113-130.

Vampola, P. 1991: Pórnatka severní - Oligoporus septentrionalis, nový choros ceskoslovenské mykoflóry. - Česká Mykol. 45: 144-149.

Volk, T.J., Burdsall, H.H., Jr. \& Reynolds, K. 1994: Checklist and host index of wood-inhabiting fungi of Alaska. - Mycotaxon 52: 1-46. 